J. Natn. Sci. Coun. Sri Lanka 199119 (2): 151-162

\title{
THE CLIMATIC WATER BALANCE APPROACH FOR THE IDENTIFICATION OF AGROCLIMATOLOGICAL REGUONS IN THE DRY ZONE OF SRY LANKA
}

\author{
K.D.N. WEERASINGHE ।
}

Department of Agronomy, Faculty of Agriculture, University of Ruhuna, Sri Lanka.
(Date of receipt : 28 December 1990)
(Date of acceptance : 07 October 1991)

\begin{abstract}
Annual and seasonal agroclimatological maps of Sri sanka are presented in respect to both Troll's Humidity Index and Hargreave's Moisture Availability Index (MAI). This helps to differentiate the Dry Zone of Sri Lanka into two distinct climatological zones with respect to both Troll's and Hargreave's Criteria. ic. "Wet-Dry Semi Arid" and "Dry Semi Arid" regions according to Troll's Humidity Index and "Moderately Deficient" and "Somewhat Deficient" moisture regions according to Hargreave's MAI. From the stand point of the MAI of the Maha season two hydrological regions could be identified, viz. Humid and Semi Arid Regions. The northern boundary between these two regions lies along Kurunegala, Mahailluppallama and Vavuniya to the eastern part of the Jaffna Peninsula. Hambantota and the castern part of the Amparai are also Semi Arid in the Maha season and rest of the island remains humid in this season. The entire dry zone is "Arid" in the Yala season.
\end{abstract}

\section{Introduction}

The climate of Sri Lanka is characterized by nearly constant temperature and high variability in rainfall. With respect to rainfall the country can be divided into three precipitation zones; Wet, Dry and intermediate zones.

Sri Lanka has been divided into 21 Agro-ecological sub zones, on the basis of a combination of different criteria such as rainfall, vegetation, forest species, soils, and present land use. Accordingly eleven agro-ecological regions have been identified for the Wet Zone, four in Intermediate zone and six in the Dry Zone. ${ }^{8}$

In the Dry Zone it is the nature of the soil and not the elevation that primarily determines the identity of the agro-ecological regions. In the Intermediate Zone both environmental elements as well as soil play an equally important role. ${ }^{8}$

From the standpoint of the vegetation climax in the Mannar Zone and the area east of Hambantota, Thambiahpillay (1960) had identified two regions having semi-arid climatic characteristics. Thus the modifred climatic region map of Ceylon by Thambipillay (1960) demarcated two semi arid regions (Bsh) in South Eastern and North Western regions of Sri Lanka according to Koppen's standards.

The aridity of a region increases in inverse proportion to rainfall. Thus different limits of precipitation have been suggested to define the arid and semi arid regions. However these limits in annual average precipitation vary from country to to country and from author to author. ${ }^{7}$

The semi arid tropics (SAT) are characterized by unpredictable rainfall, poor soils and high evaporation. Lack of moisture is the key limiting factor to stabilized and improved agriculture in these regions. ${ }^{11}$ 
The mean annual temperature of the semi arid tropics exceeds $18^{\circ} \mathrm{C}$. These areas are characterized by a high climatic water demand and by variable and erratic rainfall Here the annual values of potential evapotranspiration(PET) often exceeds $1750 \mathrm{~mm}$.

Virmani et al. ${ }^{12}$ examined seven important classification systems relating to the SA $\mathrm{T}$ enviromments. The authors concluded that classification systems using precipitation and potential evapotranspiration as inputs have a definite advantage because these are the two parameters of primary importance in the evaluation of chimatic water adequacy.

Classification methods adapted for climatic classification, based on ratios of precipitation to evaporation and their application to India are described elscwhere. ${ }^{6}$

The objective of the present paper is to identify the different Agroclimatological Regions of Sti $\mathrm{l}$ anka based on annual and seasonal climatic water balances.

\section{Materials and Methods}

The monthly rainfall and pan evaporation for 21 locations in the Dry Intermediate and Wet Zones of Sri Lanka are used for the present analysis.

The geographical positions, annual precipitation and annual pan evaporation of the selected stations are given in Table 1.

Table 1: Anmul Rainfall and Pan Evaporation of Selected Stations

\begin{tabular}{lcccc}
\hline Station & $\begin{array}{c}\text { Long } \\
E\end{array}$ & $\begin{array}{c}\text { Lat. } \\
\text { N }\end{array}$ & $\begin{array}{c}\text { Rainfall } \\
\text { mm }\end{array}$ & $\begin{array}{c}\text { Evap. } \\
\text { mm }\end{array}$ \\
\hline Colombo & 79.86 & 6.90 & 2345 & 1722 \\
Galle & 80.22 & 6.03 & 2513 & 1969 \\
Kurunegala & 80.37 & 7.47 & 2125 & 2140 \\
Nuwaraeliya & 80.77 & 6.97 & 2328 & 1382 \\
Mapalana & 80.57 & 6.07 & 2354 & 1874 \\
Hambantota & 81.13 & 6.12 & 1075 & 2229 \\
A'Pelessa & 80.90 & 6.15 & 1092 & 2426 \\
Batticaloa & 81.70 & 7.72 & 1704 & 2087 \\
Puttalam & 79.83 & 8.03 & 1110 & 2104 \\
Mahailuppallama & 80.47 & 8.12 & 1379 & 2157 \\
Trincomalee & 81.21 & 8.58 & 1649 & 2470 \\
Vavuniya & 80.50 & 8.75 & 1488 & 2039 \\
Mannar & 79.92 & 8.95 & 967 & 2135 \\
Jaffna & 80.02 & 9.65 & 1329 & 2236 \\
Badulla & 81.05 & 6.99 & 2384 & 1523 \\
Diyatalawa & 80.97 & 6.81 & 1732 & 1484 \\
Kandy & 80.63 & 7.33 & 3171 & 1983 \\
Ratnapura & 80.40 & 6.68 & 3596 & 1642 \\
Anuradhapura & 80.38 & 8.35 & 1203 & 2020 \\
Watawala & 80.60 & 6.95 & 5245 & 1500 \\
Amparai & 81.40 & 7.25 & 1538 & 2300
\end{tabular}


Computer programmes available at the Natural Resources Management Programme (DRN), IRAT/CIRAD, France were used for the data analysis. The programme "First" (Weerasinghe, Sabatier, and Luc, 1990) is used for the computation of Dependable rainfall. The Programme "UNIMAP" is used for agroclimatological mapping. Hargreave's (1971) moisture availabulity index (MAI) was calculated at monthly intervals using $75 \%$ probable rainfall as Dependable $\mathbb{R}$ ainfall and 0.75 pan evaporation as potential evapotranspiration (PET).

Hargreave's MAI and Troll's Aridity Index were used to characterize the agroclimatological zones. Climatic Water Balance was calculated according to Cochme and Franquin (1977). ${ }^{1}$

\section{Results and Discussion}

The annual rainfall distribution pattern (Figure 1), clearly illustrates the path of the North East monsoon which travels along the diagonal of the North Eastern to the South Western boundary. This explains the prevailing aridity in North Western and South Eastern boundaries of the country.

The major part of the moisture carried with the South west monsoon is dropped in the Western and South Western mountainous regions, thus keeping the South Eastern part of the country dry throughout the season.

\subsection{Agroclimatological Regions according to Troll's Classification}

Troll ${ }^{10}$ defined humid months as those in which mean rainfall exceeds mean potential evapotranspiration. The emphasis on this classification is on the duration of dry and humid months rather than on the assignment of climatic boundaries based on annual precipitation. 11

According to Troll's criteria Nuwara Eliya, Ratmapura, Kandy and Galle Districts come under Tropical Rainforest and Transitional Zones with more than 9.5 humid months in the annual cycle (Figure 2). Colombo, Badulla, Diyatalawa, Kurunegala and Matara come under Humid Savannah with 7 to 9 kumid months.

Mannar, Puttalam, Jaffna, Trincomalee and Hambantota Districts appear to be in Dry Semi Arid Tropics with $2-4.5$ bumid months. The rest of the Dry Zone falls into Wet Dry Semi Arid tropics (Dry Savannah) with 4.5 to 7 humid months.

From the hydrological standpoint, the Wet and Dry zones of Sri Lanka represent contrasting zones. But that does not mean that the Wet Zone on one hand and the Dry Zone on the other hand could be regarded as homogeneous climatic zones. The Dry Zone is differentiated in to 6 Agro Ecological Zones (DL1, DL2, DL3, DL4-DL5, and DL6) in the Agroecological map. ${ }^{8}$

Jaffna and Mannar zones (DL3 - DL6) may experience an eight month continuous period of water deficit. ${ }^{2}$ According to Thornthwite's 1948 criteria (Koelmeyer, 1958), Mannar and Hambantota are semi-arid, with no water surplus, megathermal, and equable temperature (Dd' - Aa' zones), whereas North Central areas (Anuradhapura) 

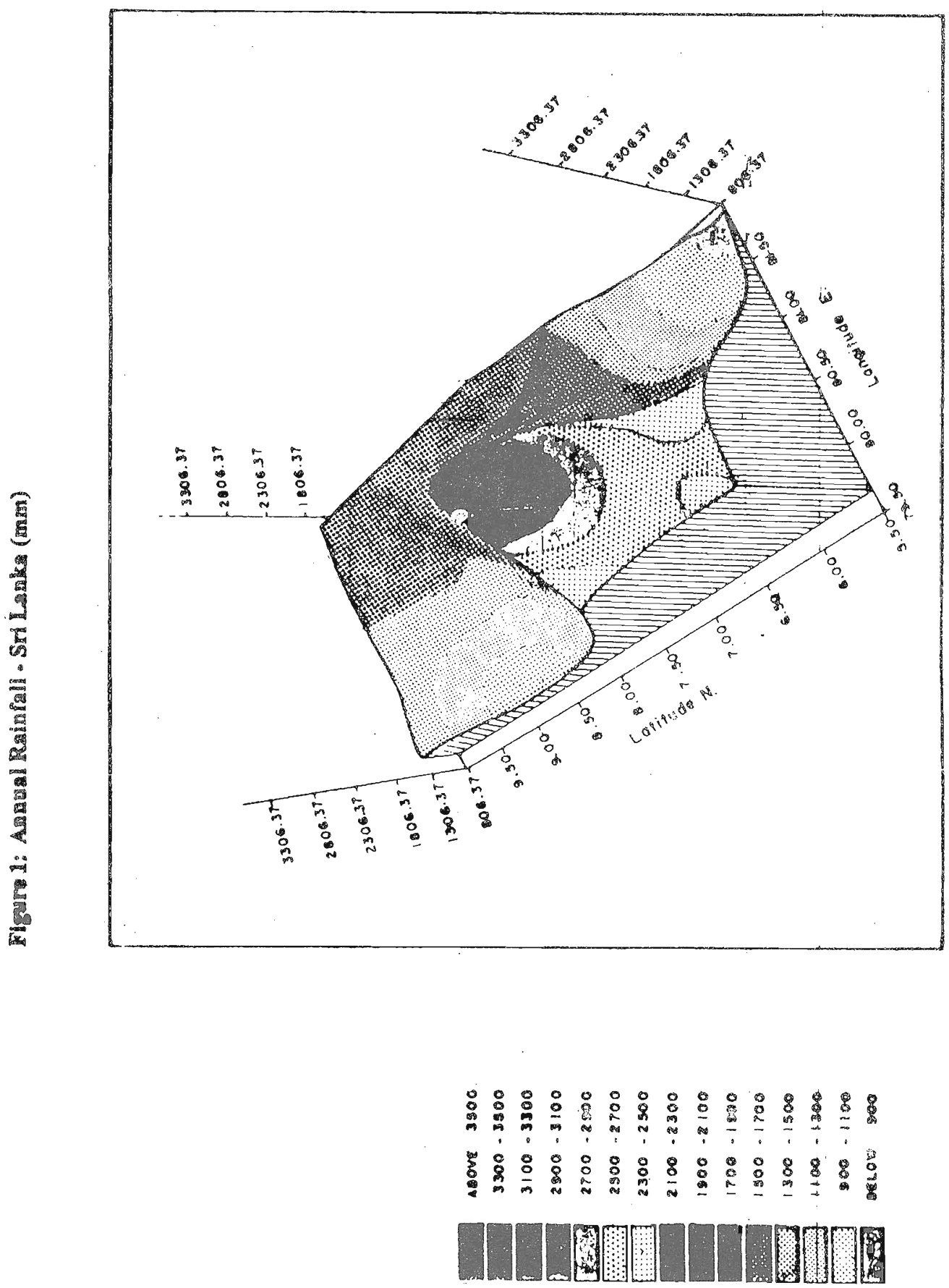
represent moist sub humid regions, which has moisture deficieacy in April - October. 5 According to the suggested modification for Koppen's standards by Thambiahpillay (1960), Hambantota and Mannar regions come under the Semi Arid Regions.

When the climatological regions identified according to Troll's, criteria are compared with the Agroecological Map ${ }^{8}$, it is clear that DL3, DL4, DL5, and DL6 zones in the Agroecological map represent the Dry Semi Arid Tropics with 2.0 to 4.5 bumid months (Figure 2). DL1 zone of the Agroecological Map, represents Wet Dry Semi Arid Tropics with 4.5 to 7 humid months; Furthermore Intermediare Zone, enters in to Humid Savannah with 7.0 to 9.5 humid months in the annual cycle.

This classification indicates that almost all of the Dry Zone of Sri Lanka is Wet or Dry Semi Arid Tropics.

\subsection{Agroclimatological Regions, according to the Hargreave's Moisture Avainability Dndex (MAl)}

Hargreaves (1971) defined MAI as the ratio of the rainfall value expected with $75 \%$ probability to the estimated potential evapotranspiration for the period concerned.

This approach is followed by a number of authors to classify the Dry or Semi Arid Regions of India. ${ }^{6}$ As to the annual MAI, Jaffna, Mannar, Puttalam, Ampara, Hambantota, Tangalle, Anuradhapura, and Vavuniya, may be designated as Moderately Deficient Moisture Regions (MAI > 0.34-0.67) (Figure 3).

Mahailluppallama and Angunakolapelessa are in the Northern and Southern boundaries of the 'Somewhat Deficient' Moisture Regions. Diyatalawa, Kandy and Galle constitute a circle of Adequate Moisture with annual MAI of 1.05 to 1.35. The internal mountainous regions seem to be in Excessive Moisture Region with MAI 1.35 .

According to Hargreave's Annual Moisture Availability Index part of the Dry and Intermediate Zones of Sri Lanka could be considered to be Moderately Deficient Moisture Regions. However Hambantota, Mannar, Jaffna, and Puttalam areas have less moisture availability compared to other "Moderately Deficient Moisture Regions" (Figure 3).

The Agroclimatological Classification of the Dry Zone based on moisture availability of the individual seasons, viz Yala and Maha seasons may give better estimation of moisture in respect to the Dry and Intermediate zones.

Hargreaves (1971) classified the climate as Semi Arid if there are 3 to 4 consecutive months in the annual cycle with MAI $>0.34$.

The number of consecutive months with MAI above 0.34 in the Yala and Maha seasons are given in Figures 4 and 5 .

A comparison between the regions covered under MAI of the Maha Season and the seasons demarcated by Troll's criteria show a reasonable similarity. The Semi Arid Tropic with $2.0-4.5$ humid months in respect to the Troll's criteria could be 


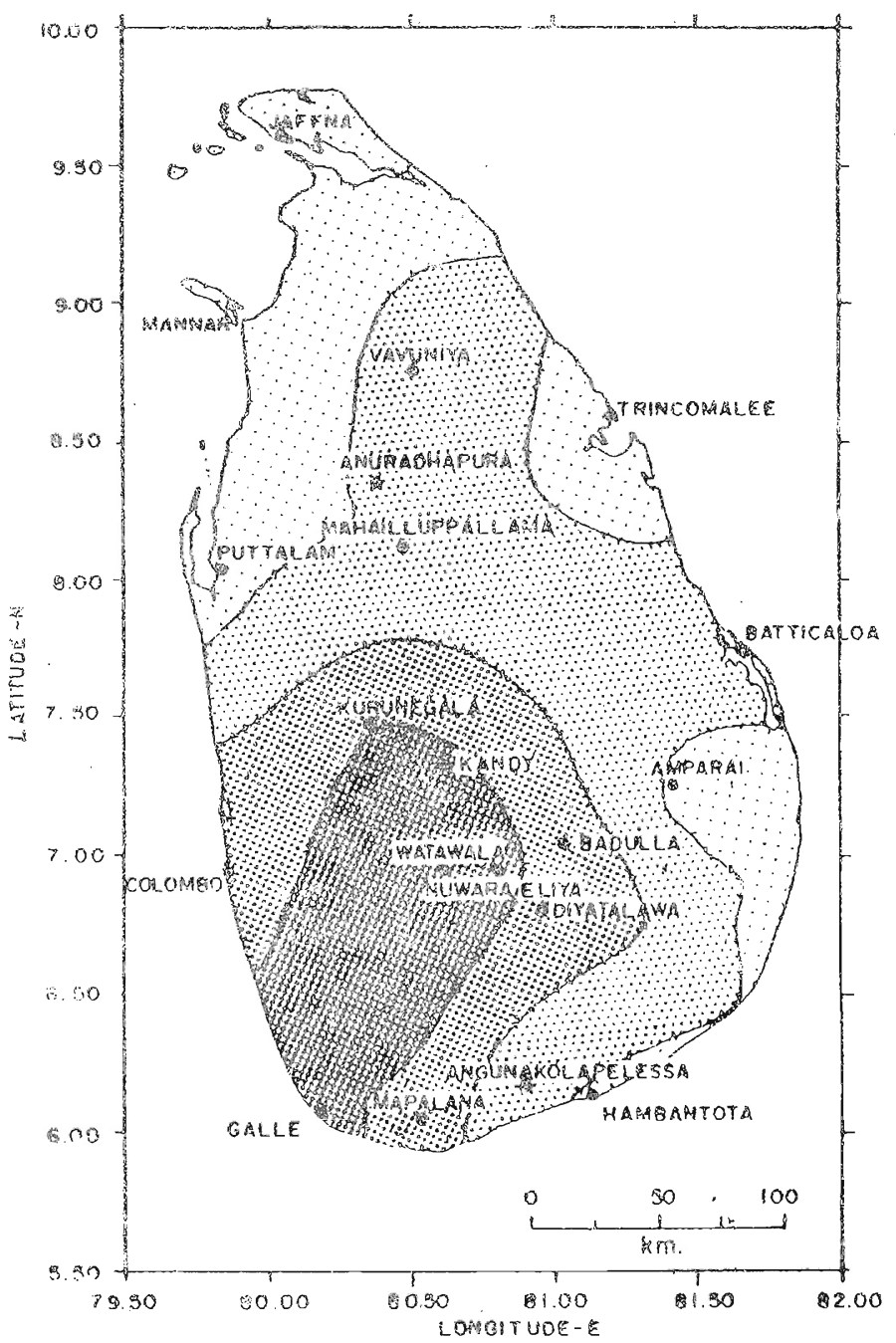

HUMIO MONTIS

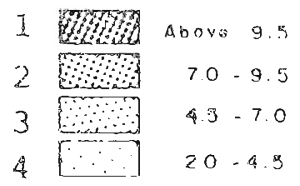

Figure 2: Climatological regions in respect o Troll's Criteria, Sri Lanka.

1. Tropical rainforest and transitional wood.

2. Mumid Savannaha.

3. Wet dry semi aria tropics (Dry Savannah).

4. Dry semi arid tropics (Thorn Savannah). 


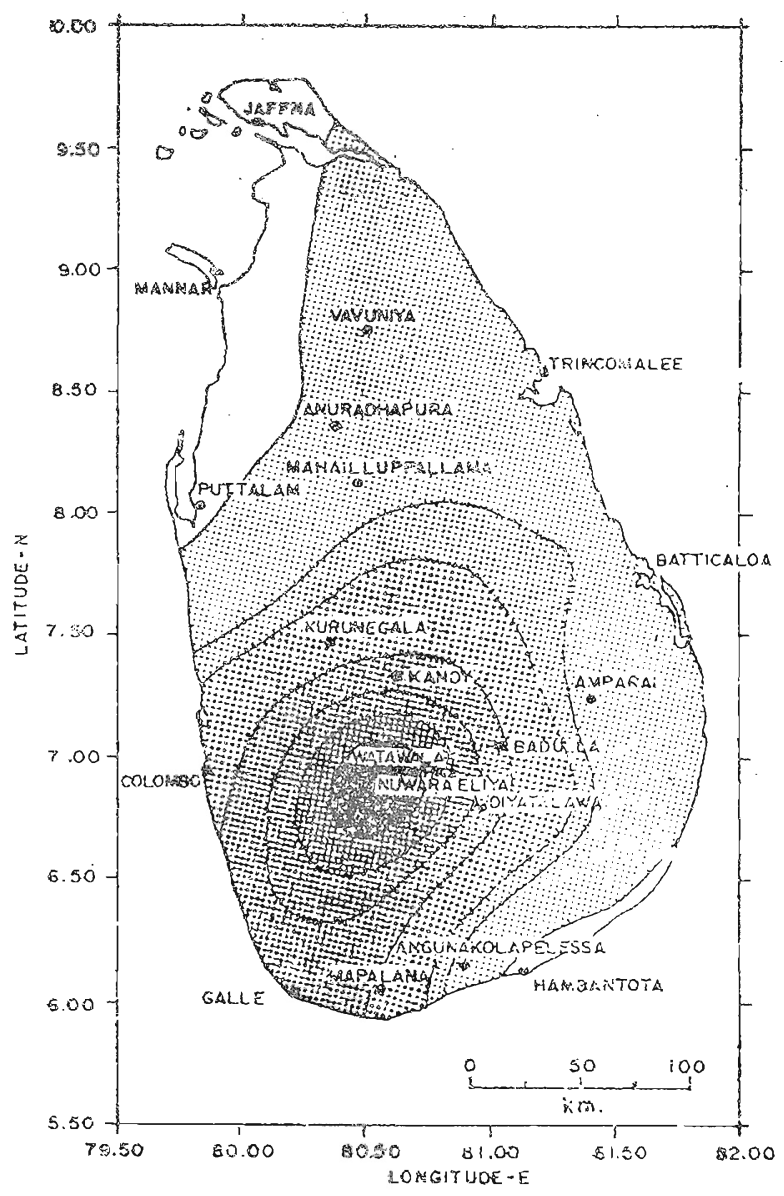

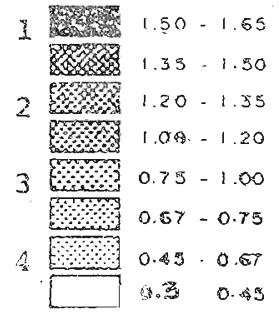

Figure 3: Annual Moisture Avallability indices (MAI), Sri Lanka accroding to Hargreave's Classification.

1. Excessive moisture region.

2. Adequate moisture region.

3. Somewhat deficient moisture region.

4. Moderately deficient moisture region. 

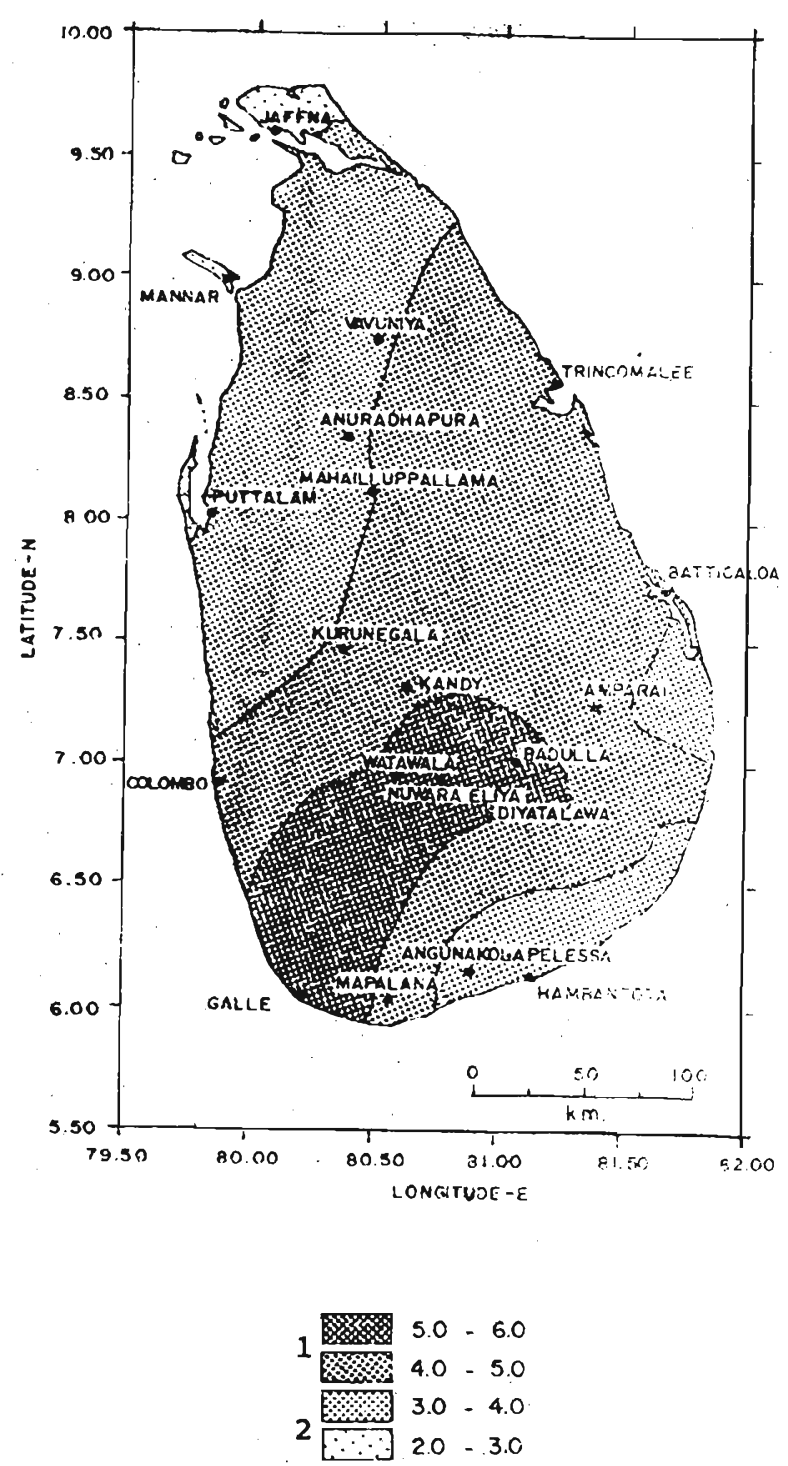

Figure 4: Number of Consecutive Months with 'MAI' above 0.34 in Maha Season.
1. Humid region
2. Semi arid region 


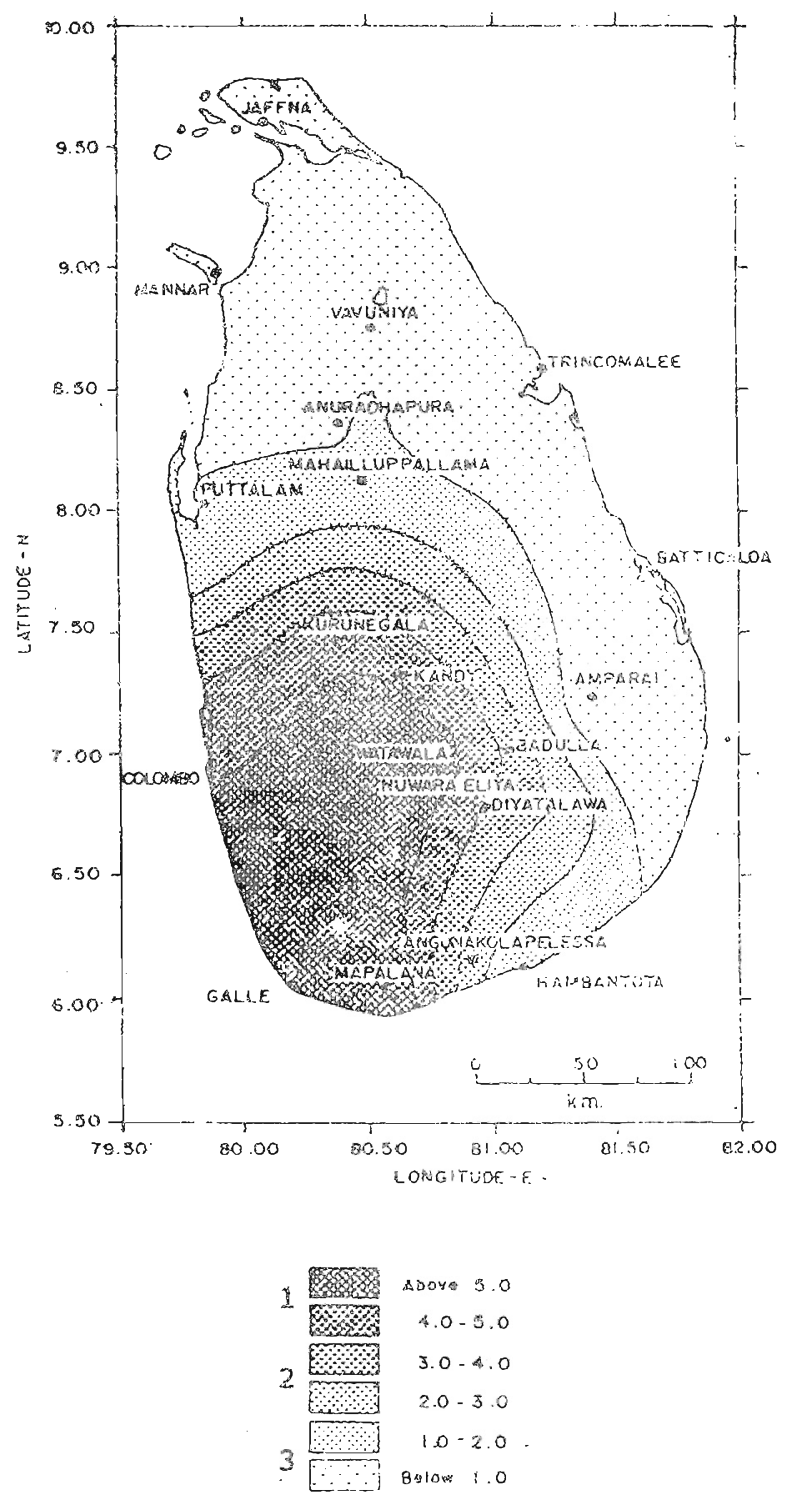

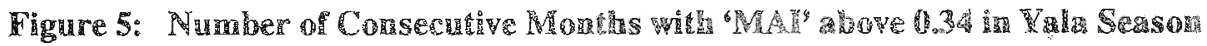

1. Humid region

2. Semi arid region

3. Arid region 
considered to be "Semi Arid" in relation to the Mana seasou as well. Wevertheless Vavuniya and Anuradhapura districts which are in the Wet Dry Semi Arid tropics according to Troll's criteria are considered as Semi Arid Tropics in relation to the MAl of the Maha season. The Maha season in Jafna and Mamat appears to be shorter compared to other Semi Arid Areas which agrees with the earlier classification by pomoros (1978). The boundary line between Humid and Semi Ard Regions ies along Kurunegala, Wahalluppallama and Vavniya to the Northern Yenixsula. Hambantota and the Easter part of the Amparai District are also included in the Semi Arid Region. Nevertheless the North Easterm and Eastern Diry Zome and the Tntermediate Zones remain bumid with more than 45 to 5.0 humid months in the Maha season, (nigure 4).

The entire Dry Zone seems to be arid during the Yala season. Putalam, Mambantota, Mahailluppallama and Vavuniya have 1 to 2 months with $\mathbb{M A}>0.34$; While rest of the Dry Zone have less than one month with MAI $>0.34$ in the Yala season. The kntermediate Zone could be considered to be Semi Arid during the Yala season (Figure 5).

\section{Coneriusions}

The Dry Zone of Sri Lanka can be differentiated into two distinct Agroclinatological Zones according to both Troll's and Hargreaves' Indices; ie. regions with 4.5 to 7 humid months (Wet Dry Semi Arid Tropics) and regions with 2 to 4.5 humid months (Dry Semi Arid "Tropics) according to Troll and "Moderately Deficient" and "Somewhat Deficient" moisture regions according to Hargreave"s MAL.

From the stand point of the Climatic Water Balance Approach for the "Maha" season, two hydrological regions could be identifed, viz. Humid and Semi Arid regions, and for the Yala season three Hydrological Regions, viz. Humid, Scmi Arid and Arid regions. The entire Dry Zone is 'Arid' in the Yala season.

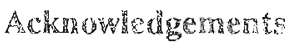

The present work was completed with the assistance offered by Farming Systems Research Unit ORSTOM, Montpellier, and IRAT/CIRAD, France during the author's tellowhip visit to France. The author gratefully acknowledges the assistance of the many members of the staff of the "Progran Hydraulique" IRAT/CIRAD in respect of this work

Special thanks are due to Dr J.L. Sabatier (IRAT/CIRAD) and Dr M. Millville (ORSTOM) for providing necessary assistance to carry out this work.

Assistance offered by the Director of the Meteorological Department and the Assistant Director Mr M.A. Amaradasa to use the rainfall nles of the Meteorological Deparment is gratefully acknowledged. Mr C. Rathnayake, and Miss S. Pathirana are tanked for the technical assistance. 


\section{peferences}

1. COCHME ET RRAJUUMN P. (1977) Etude Agrochmanque dans une zone semi-aride eu Arrque au Sud de Sahara. Note Technique Mo. Bf IRAT. Yrance.

2. DOMOROS M. (1978) Introduction to the Chmate and Water Balance of Ceylon, Bonn, W. Germany.

3. HARGREAVES G.M. (1971) Precipication Dependability and Potential for Agriculural Production in North-East Brazl. Publication No. 74 Utab State University U.S.A.

4. JACXSON Y. (1977) Clmate Water and Agriculture in the Tropics. Longman, Londor.

5. KOELMEYER K.O. (1958) Climate Classification and the Distribution of Vegetation in Ceylon. X. Ceylon Forester (4), 265-288

6. KRUSHNAN A. (1980) Agrodimatic Classification Methors and their Application to India, Climatic Classificaton. A Consultants Mecting. ICRPAT 33-115.

7. MOHER-HOMYIV.M. (1980) Classincation of Semi-Arid Tropics; Climatie and Poytogeographic Approaches; Chmatic Classification, A Consulants* Meeting. ICRISAT 7-16.

8. Nationak Allas of Sri Lanka, "Agro Ecology", Sri Lanka Survey Dept. 1981.

9. THAMBIAHPLLAY G. (1960) Clmatic Regions of Ceylon According to the Koppen Classification. J. Tropical Agriculurist CXV., 147-166.

10. TROLL C. (1966) Seasonal Climate of the Earth. The Scasonal Course of Natural Phenomena in the Different Climatic Zones of the Earth. WOrld Map of Climarology 19-28.

11. VIRMANI S.M . (1980) Need Relevance and Objectives of the Consultants Meeting on Climatic Classification; A Consultants' Meeting. ICRISAT 7-16.

12. VIRMAIJI SM. SIVAKUMAR M.V.K. \& REDDY G.J. (1982) Raintall probability estimate for selected locations of Semi Arid-India, Research report 1 , ICRISAT India.

13. WEERASINGHE K.D.N. (1989) The Rainfall Probabihty Analysis of Mopara and its Application to Aricultural Production of the Area. J. Nain. Sci. Coun. Sri Lanka $17,(2)$ 173-186.

14. WEERASINGHE K.D.N. (1989) Rainfall Analysis of Nilwala Areas, Southem Sri Lanka in Relation to the Rice Cropping Systems. Research report, DRN, IRAT, Montpellier, France.

15. WEERASINGHE K.D.N., SABATTER J.L., \& GRANDGEAN LUC (1990) Manual for "First"; A Computer Program for Agroclimatological Data Analysis, User's Manual, University of Ruhuna. Faculty of Agriculture, Matara. 